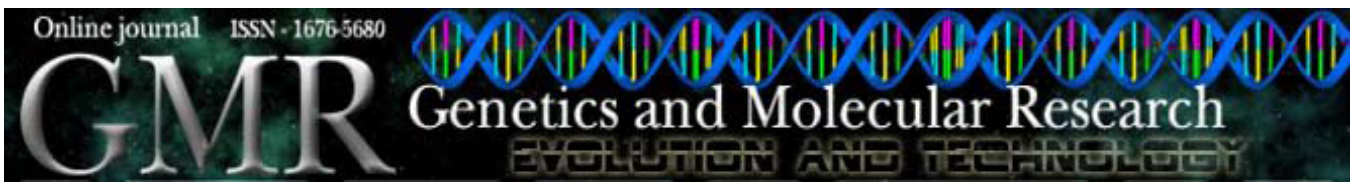

\title{
Genetic distances between popcorn populations based on molecular markers and correlations with heterosis estimates made by diallel analysis of hybrids
}

\author{
R.E.F. Munhoz ${ }^{1}$, A.J. Prioli ${ }^{1}$, A.T. Amaral Júnior ${ }^{2}$, C.A. Scapim ${ }^{1}$ \\ and G.A. Simon ${ }^{1}$ \\ ${ }^{1}$ Departamento de Agronomia, Universidade Estadual de Maringá, \\ Maringá, PR, Brasil \\ ${ }^{2}$ Laboratório de Melhoramento Genético Vegetal, \\ Universidade Estadual do Norte Fluminense Darcy Ribeiro, \\ Campos dos Goytacazes, RJ, Brasil \\ Corresponding author: C.A. Scapim \\ E-mail: ca-scapim@uol.com.br
}

Genet. Mol. Res. 8 (3): 951-962 (2009)

Received February 2, 2009

Accepted May 28, 2009

Published August 11, 2009

\begin{abstract}
Diallel analysis was used to obtain information on combining ability, heterosis, estimates of genetic distances by random amplified polymorphic DNA (RAPD) and on their correlations with heterosis, for the popcorn varieties RS 20, UNB2, CMS 43, CMS 42, Zélia, UEM J1, UEM M2, Beija-Flor, and Viçosa, which were crossed to obtain all possible combinations, without reciprocals. The genitors and the $36 \mathrm{~F}_{1}$ hybrids were evaluated in field trials in Maringá during two growing seasons in a randomized complete block design with three replications. Based on the results, strategies for further studies were developed, including the construction of composites by joining varieties with high general combining ability for grain yield (UNB2 and CMS 42) with those with high general combining ability for popping expansion (Zélia, RS 20 and UEM M2). Based on the RAPD markers, UEM J1 and Zélia were the most genetically distant and RS 20 and UNB2
\end{abstract}


were the most similar. The low correlation between heterosis and genetic distances may be explained by the random dispersion of the RAPD markers, which were insufficient for the exploitation of the popcorn genome. We concluded that an association between genetic dissimilarity and heterosis based only on genetic distance is not expected without considering the effect of dominant loci.

Key words: Popcorn; Molecular markers; Diallel analysis; Heterosis; Genetic divergence; Zea mays

\section{INTRODUCTION}

Popcorn is a highly appreciated food product in Brazil; nevertheless, the values of popping expansion and texture as well as yields of the national cultivars do not meet expectations. The best populations for breeding programs of the crop should be chosen based on traits defined by breeders to obtain the best hybrids in terms of high yield and popping expansion values, to satisfy both producers and consumers. However, negative correlations between these traits have been reported in several studies (Verma and Singh, 1979; Andrade et al., 2002; Scapim et al., 2002; Daros et al., 2004a,b; Freitas Júnior et al., 2006; Santos et al., 2008).

In this context, one of the most interesting genetic-statistical techniques is the diallel analysis of crosses, in view of the great amount of genetic information it can provide. Such crosses have therefore attracted interest in the world literature, in many breeding programs with different crops (Amaral Júnior et al., 1999; Scapim et al., 2002; Vieira et al., 2007; Rangel et al., 2007, 2008; Aguiar et al., 2008; Balestre et al., 2008; Gonçalves et al., 2008, 2009; Vilela et al., 2008).

The pre-selection of genitors is an essential step in the prediction of hybrid performance. The traditionally applied methodology for this purpose is the formation of heterotic groups, based on the evaluation of the pedigree data and its relation with the heterosis values based on morphological traits of interest (Franco et al., 2001; Mohammadi and Prasanna, 2003; Miranda et al., 2008). More recently, molecular markers have been used to detect the variation in the DNA sequence underlying the analysis of the existing genetic dissimilarity of the parents. These markers have the advantage of simplifying the screening of parents, which can be done directly in the DNA evaluation (Mohammadi and Prasanna, 2003; Crossa and Franco, 2004; Legesse et al., 2008; Balestre et al., 2008; Dandolini et al., 2008; Silva et al., 2009).

Allele-based estimates of genetic distances by techniques using molecular markers allow the substitution of heterotic groups by crosses between contrasting parents (Hahn et al., 1995; Pejic et al., 1998). It is worth noting the importance of early identification of genotypes, to facilitate the selection and recombination process of plants with desirable traits and to reduce the time required to conclude one breeding generation (Mohammadi and Prasanna, 2003; Cruz et al., 2004).

A positive correlation between the genetic distance of the parents detected by molecular markers and heterosis expressed in the hybrids has been reported in some cultivated plant species such as rice (Xiao et al., 1996) and melon (Garcia et al., 1998). On the other hand, Barbosa-Neto et al. (1996), Cerna et al. (1997) and Lorencetti et al. (2006) found no correlation between genetic dissimilarity and heterosis data of wheat, soybean and oat yield, respectively. 
For maize, the results available for the use of molecular markers to predict heterosis cannot be considered conclusive. Dudley et al. (1991) found no significant correlation between these variables in maize. Lee et al. (1989) performed a diallel analysis focused on the heteromorphism of the loci detected in eight maize lines and found a small significant and positive correlation with the cultivated hybrids. Moreover, Lanza et al. (1997) obtained a significant correlation between grain yield data and random amplified polymorphic DNA (RAPD)-based genetic distances. Besides, Balestre et al. (2008), with the aim of correlating the genetic distance of single cross hybrids with yield, heterosis and specific combining ability (SCA) in the double cross hybrid synthesis, concluded that there was a moderate correlation between genetic distance and heterosis $(r=0.40)$ and genetic distance and SCA $(r=0.38)$, but the authors found that the molecular markers were efficient in placing hybrids in different heterotic groups and were also useful in eliminating the most negative heterosis and SCA.

The objectives of this study were to use the different strategies for breeding to predict the real potential of hybrids using genetic distances based on RAPD markers and to evaluate the relationship between heterosis and the genetic distance detected in intervarietal popcorn hybrids.

\section{MATERIAL AND METHODS}

\section{Field experiment}

The popcorn populations (CMS 42, CMS 43, RS 20, UNB2, Viçosa, Beija-Flor, UEM J1, UEM M2, and Zélia) were sowed in four rows of $10.0 \mathrm{~m}$ paired and intercrossed on a complete diallel scheme, without reciprocal crosses.

The trials were conducted on experimental fields of the Universidade Estadual de Maringá in two growing seasons (98/99 and 99/00), in a complete randomized block design with three replications and 45 treatments. Each plot consisted of 2 rows of $5.0 \mathrm{~m}$, spaced $0.9 \mathrm{~m}$ apart.

\section{Agronomic traits evaluated}

The following traits were evaluated: grain yield, corrected for a moisture content of $15.5 \%$, expressed in $\mathrm{kg} / \mathrm{ha}$, and popping expansion, which was estimated from random samples from the harvest plot. For popping expansion, the volume in $\mathrm{cm}^{3}$ of $40 \mathrm{~g}$ grains with $12 \%$ moisture was measured before and after popping, producing the corresponding ratio (popping expansion = volume after popping / volume before popping). The grains were popped in an electric popper with automatic temperature control, at $237^{\circ} \mathrm{C}$, using two samples from each plot.

\section{RAPD analyses}

Leaf tissue of $0.3 \mathrm{~g}$ was obtained from 20-day-old seedlings in 32 plants per each genotype. After being cut into small pieces without the middle nervure (Vilela et al., 2008), the weighed tissues were immediately transferred to bags containing $1.5 \mathrm{~mL}$ cetyl trimethyl ammonium bromide as in the protocol described by Iqbal et al. (2007). The material was completely homogenized with a hand holler. After incubation, at $65^{\circ} \mathrm{C}$ for $30 \mathrm{~min}$, the homogenized leaf tissues were transferred to two 1.5-mL Eppendorf tubes. Equal volumes $(0.75 \mathrm{~mL})$ of chloroform and isoamyl alcohol were added and the tubes were inverted 
5-10 times, followed by centrifugation at 13,000 rpm for $10 \mathrm{~min}$. After centrifugation, 800 $\mu \mathrm{L}$ supernatant was transferred from both tubes to another 1.5-mL Eppendorf tube. Next, approximately $700 \mu \mathrm{L}$ isopropanol was added to the supernatant $(800 \mu \mathrm{L})$ and mixed by inverting the tube about ten times. The DNA was pelleted, washed and resuspended in $150 \mu \mathrm{L} 0.1 \mathrm{X}$ Tris-EDTA. The concentration of DNA was measured at $260 \mathrm{~nm}$ in a spectrophotometer (Spekol UV VIS, Zeis) by a comparison with phage $\lambda$ DNA of known concentration. The quality of DNA was checked by running $5 \mu \mathrm{L}$ DNA on a $0.8 \%$ agarose gel prepared in $0.5 \mathrm{X}$ Tris-borate-EDTA buffer. As described by Iqbal et al. (2007), the DNA samples that produced undefined smears on the gel were rejected.

The DNA samples were amplified in a thermal cycler (Perkin-Elmer DNA Thermal Cycler), according to Williams et al. (1990). Ten primers with best definition and highest number of polymorphic bands were used: OPA-20, OPX-17, OPX-19, OPW-1, OPW-2, OPW-5, OPW-6, OPW-7, OPW-15, and OPW-16.

\section{Data analyses}

Based on the polymorphic bands, a binary data matrix was created where the values (1) and (0) indicate, respectively, the presence and absence of a band, underlying the calculation of genetic distances among pairs of popcorn materials using Nei's distance (1972) as well as the construction of a dendrogram by the unweighted pair group method using arithmetic averages (Cruz and Carneiro, 2003; Cruz et al., 2004).

The sums of squares of treatments were partitioned into SCA and general combining ability (GCA), using method 2, on model 1 of Griffing (1956). Thereafter, heterosis was evaluated by the method of Gardner and Eberhart (1966). The Genes program (Cruz, 2006) was used in the analytic procedure.

The relation between the binary genetic distances and the values of heterosis and SCA was evaluated by Pearson correlations, using the Genes software (Cruz, 2006). The traits to obtain the correlations were grain yield and popping expansion.

\section{RESULTS AND DISCUSSION}

The effect of treatments and the partitions of GCA and SCA and all interactions were significant $(\mathrm{P}<0.05)$ for yield and popping expansion. This shows genetic variability in the populations under study and the expression of additive and non-additive gene effects in the varietal crosses, which represents a favorable situation for breeding. The coefficient of variation for grain yield was $17 \%$ on jointed analysis indicating medium experimental precision (Scapim et al., 1995). For popping expansion, the estimate of coefficient of variation was $12 \%$, and according to Scapim et al. (2002) and Simon et al. (2004), this value can be considered small.

The $\hat{S}_{i i}$ effect represents the SCA of a variety with itself. Cruz and Vencovsky (1989) demonstrated that each $\hat{S}_{i i}$ is an indicator of the direction of dominance deviations, which is positive when the trait is reduced and negative otherwise. In terms of the diversity of gene frequencies in the cultivars, the authors further reported that in absolute values the $\hat{S}_{i i}$ values are highest for cultivars of greatest genetic diversity, compared to the mean gene frequencies in the diallel. Moreover, the sum of all $\hat{S}_{i i}$ is a linear function of mean heterosis. 
It was noted that the dominance deviations generally increased grain yield values (Table 1), in accordance with Dofing et al. (1991), Larish and Brewbaker (1999), Pereira and Amaral Júnior (2001), Scapim et al. (2002), Viana and Matta (2003), Simon et al. (2004),

\begin{tabular}{|c|c|c|c|c|c|c|}
\hline \multirow[t]{3}{*}{ Genitors and $\mathrm{F}_{1 ' \mathrm{~s}}$} & \multicolumn{2}{|c|}{ GY } & \multirow[t]{3}{*}{ Mean (kg/ha) } & \multicolumn{2}{|c|}{$\mathrm{PE}$} & \multirow[t]{3}{*}{ Mean $(v / v)$} \\
\hline & \multicolumn{2}{|c|}{$\left(\hat{S}_{i i}\right.$ and $\left.\hat{S}_{i j}\right)$} & & \multicolumn{2}{|c|}{$\left(\hat{S}_{i i}\right.$ and $\left.\hat{S}_{i j}\right)$} & \\
\hline & 98/99 & $99 / 00$ & & $98 / 99$ & $99 / 00$ & \\
\hline Beija-Flor & -168.304 & -724.05 & 1549 & -1.55 & 2.22 & 11.4 \\
\hline Viçosa & -697.54 & -375.36 & 1629 & 0.43 & 5.40 & 12.2 \\
\hline UNB2 & 79.62 & -263.82 & 2740 & -2.02 & 1.09 & 11.8 \\
\hline Zélia & 168.30 & 547.24 & 1204 & 1.60 & -0.47 & 17.9 \\
\hline CMS 43 & -263.17 & 334.18 & 2132 & -3.72 & 0.73 & 11.8 \\
\hline CMS 42 & -854.62 & -795.28 & 1537 & -3.52 & -0.30 & 10.6 \\
\hline RS 20 & -75.00 & -126.00 & 869 & 2.27 & 2.97 & 20.3 \\
\hline UEM M2 & -176.12 & -497.75 & 1366 & -2.97 & 2.48 & 15.9 \\
\hline UEM J1 & -877.59 & -445.20 & 1585 & -3.67 & -0.01 & 8.0 \\
\hline Beija-Flor x Viçosa & 666.313 & 844.647 & 2836 & 1.440 & -4.693 & 8.6 \\
\hline Beija-Flor x UNB2 & 536.184 & -73.167 & 2645 & -2.933 & 3.053 & 11.7 \\
\hline Beija-Flor x Zélia & -501.447 & -251.224 & 1402 & -3.478 & -0.875 & 12.0 \\
\hline Beija-Flor x CMS 43 & -198.596 & 399.381 & 2146 & 2.767 & -1.475 & 12.8 \\
\hline Beija-Flor x CMS 42 & 160.738 & 292.111 & 2244 & -1.733 & -0.838 & 10.5 \\
\hline Beija-Flor x RS 20 & 465.119 & 1183.366 & 2307 & 3.758 & 4.444 & 18.5 \\
\hline Beija-Flor x UEM M2 & -12.725 & -559.219 & 1563 & 2.940 & -6.102 & 12.0 \\
\hline Beija-Flor x UEM J1 & -458.833 & -387.795 & 1697 & 0.340 & 2.053 & 11.7 \\
\hline Viçosa x UNB2 & 818.510 & 686.643 & 3251 & -2.842 & -2.856 & 7.9 \\
\hline Viçosa x Zélia & 278.063 & -223.774 & 1888 & -2.287 & 1.516 & 12.9 \\
\hline Viçosa x CMS 43 & -35.910 & -11.200 & 2107 & -0.442 & -1.184 & 10.5 \\
\hline Viçosa x CMS 42 & 1166.783 & 1048.338 & 3371 & -0.042 & -0.547 & 10.6 \\
\hline Viçosa x RS 20 & -641.352 & -544.140 & 974 & -4.851 & -4.865 & 8.6 \\
\hline Viçosa x UEM M2 & -392.924 & 67.824 & 1771 & 2.731 & 3.389 & 15.8 \\
\hline Viçosa x UEM J1 & 465.407 & 1117.616 & 1414 & 5.431 & -1.556 & 11.5 \\
\hline UNB2 x Zélia & -530.956 & 322.016 & 2092 & 3.140 & 1.662 & 17.2 \\
\hline UNB2 x CMS 43 & 234.757 & -560.570 & 2301 & 0.785 & -0.538 & 12.9 \\
\hline UNB2 x CMS 42 & -1034.557 & 137.583 & 2149 & 4.285 & -2.702 & 13.2 \\
\hline UNB2 x RS 20 & -815.171 & -578.763 & 1204 & 1.976 & 1.580 & 16.7 \\
\hline UNB2 x UEM M2 & -174.310 & 304.820 & 2333 & -1.742 & -1.665 & 12.5 \\
\hline UNB2 x UEM J1 & 806.294 & 289.078 & 3087 & 1.358 & -0.711 & 11.4 \\
\hline Zélia x CMS 43 & 407.797 & -394.047 & 1836 & 3.140 & 0.435 & 17.0 \\
\hline Zélia x CMS 42 & 694.889 & 184.719 & 2402 & 0.940 & 4.271 & 17.5 \\
\hline Zélia x RS 20 & -538.734 & 198.976 & 1096 & -1.169 & -3.347 & 15.2 \\
\hline Zélia x UEM M2 & -150.638 & -146.307 & 1483 & 0.913 & -0.793 & 16.8 \\
\hline Zélia x UEM J1 & 677.611 & 1404.107 & 2945 & -4.387 & -1.938 & 10.4 \\
\hline CMS 43 x CMS 42 & -407.650 & -212.912 & 1919 & 0.385 & 0.371 & 13.3 \\
\hline CMS 43 x RS 20 & 405.305 & 59.410 & 1765 & -6.924 & -2.547 & 10.7 \\
\hline CMS 43 x UEM M2 & 400.926 & 444.531 & 2322 & 4.458 & -0.193 & 16.8 \\
\hline CMS 43 x UEM J1 & 280.283 & -392.945 & 1835 & 3.258 & 3.662 & 15.0 \\
\hline CMS 42 x RS 20 & 211.008 & -334.286 & 1604 & -1.024 & -0.911 & 14.1 \\
\hline CMS 42 x UEM M2 & 337.528 & 748.211 & 2525 & 1.058 & -0.456 & 14.6 \\
\hline CMS 42 x UEM J1 & 901.973 & -273.221 & 2619 & 3.158 & 1.398 & 13.5 \\
\hline RS 20 x UEM M2 & 416.940 & -482.946 & 1303 & 0.549 & 1.725 & 18.0 \\
\hline RS 20 x UEM J1 & 646.382 & 750.165 & 2306 & 3.149 & -2.020 & 14.3 \\
\hline UEM J1 x UEM M2 & -72.560 & 618.589 & 2248 & -4.969 & -0.865 & 10.1 \\
\hline
\end{tabular}


Freitas Júnior et al. (2006), Rangel et al. (2007, 2008), and Miranda et al. (2008). For popping expansion, the $\hat{S}_{i i}$ values were positive and negative in the two growing seasons, which is evidence of the existence of bidirectional dominance on the expression of this trait. Similar results were obtained by Larish and Brewbaker (1999), Scapim et al. (2002), Vilarinho et al. (2002), and Viana and Matta (2003).

Regarding the $\hat{g}_{i}$ estimates for grain yield, the genitors UNB2 and CMS 42 had the highest values, demonstrating a perspective of a high-level of gene accumulation. Among the hybrids involving variety UNB2, the $\hat{S}_{i j}$ of combination Viçosa x UNB2 was highest in both growing seasons. In relation to the hybrids involving variety CMS 42, the $\hat{S}_{i j}$ was highest for Viçosa x CMS 42. For popping expansion, among the hybrids involving variety Zélia, the $\hat{S}_{i j}$ estimate was greatest for UNB2 x Zélia, in both growing seasons, while RS $20 \mathrm{x}$ Beija-Flor stood out among the hybrids involving RS 20. Of the hybrids involving UEM M2, $\hat{S}_{i j}$ was highest for UEM M2 x Viçosa (Table 1).

The difficulty of joining high yield and good popping expansion in the same hybrid was demonstrated, since the hybrids Viçosa x UNB2 and Viçosa x CMS 42, the most desirable in terms of yield, performed worst for expansion, while the yield means of hybrid RS $20 \mathrm{x}$ Beija-Flor, most desirable in terms of expansion, were below desirable limits for the release of an intervarietal hybrid. Based on the results, different strategies for further studies could be established, such as the synthesis of composites for intrapopulation breeding programs, indicating composites by jointed materials with GCA for grain yield (UNB2 and CMS 42) with those with high GCA for popping expansion (Zélia, RS 20 and UEM M2).

Miranda et al. (2008), working with five genitors in a diallel scheme crossing proceeding from advanced generations of the popcorn hybrids (IAC 112 and Zélia) and three open-pollinated varieties (RS 20, Branco and SAM), concluded that it would be difficult to obtain commercial hybrids directly from the Brazilian local varieties because they have poor performance in popping expansion.

With respect to method of Gardner and Eberhart (1966), the mean squares of cultivar and heterosis effects were significant (at 5\% probability) for all traits, indicating that the cultivars do not form a homogenous group and that heterosis is expressed in their hybrids. For the trait grain yield, the interactions heterosis (mean, variety and specific) by years were significant $(\mathrm{P}<0.05)$, indicating the existence of sufficient variance in the gene frequencies of the cultivars and that some of them differ from each other in mean gene frequencies or the dispersion degree of these frequencies. Differences between degrees of complementation of the frequencies are also possible. Besides, these effects were not constant when considering the two growing seasons. Regarding the popping expansion, the mean squares were not significant (at 5\% probability), unlike the mean squares of the variety and specific heterosis. This fact confirms the existence of bidirectional dominance on expression, in accordance with Larish and Brewbaker (1999), Scapim et al. (2002), Vilarinho et al. (2002, 2003), and Viana and Matta (2003).

The estimates of specific heterosis of the hybrids $\left(\hat{S}_{i j}\right)$ based on the method of Gardner and Eberhart (1966) are shown in Table 2. For grain yield, heterosis in some hybrids was positive and inconsistent in the two growing seasons. It may be concluded that for this trait the dominance deviations proceeded predominantly in the direction of increasing yields. For popping expansion, $\hat{S}_{i j}$ values were positive and negative in the two growing seasons, consistently indicating the existence of bidirectional dominance in the 
Table 2. Estimates of specific heterosis $\left(\hat{S}_{i j}\right)$ according to the method of Gardner and Eberhart (1966), for the traits grain yield (GY) and popping expansion (PE) evaluated in 36 popcorn hybrids in two growing seasons.

\begin{tabular}{|c|c|c|c|c|}
\hline \multirow[t]{2}{*}{ Hybrid } & \multicolumn{2}{|c|}{ GY } & \multicolumn{2}{|c|}{$\mathrm{PE}$} \\
\hline & 98/99 & $99 / 00$ & 98/99 & $99 / 00$ \\
\hline Beija-Flor x Viçosa & 1100.0 & 1394.0 & 2.0 & -8.5 \\
\hline Beija-Flor x UNB2 & 580.5 & 420.7 & -1.2 & 1.4 \\
\hline Beija-Flor x Zélia & -333.2 & 384.4 & -3.5 & -1.7 \\
\hline Beija-Flor x CMS 43 & 17.2 & 594.3 & 5.4 & -3.0 \\
\hline Beija-Flor x CMS 42 & 350.7 & 1051.8 & 0.8 & -1.8 \\
\hline Beija-Flor x RS 20 & 587.0 & 1608.4 & 3.4 & 1.8 \\
\hline Beija-Flor x UEM M2 & 159.5 & 51.7 & 5.2 & -8.4 \\
\hline Beija-Flor x UEM J1 & 64.1 & 196.8 & 2.9 & 1.0 \\
\hline Viçosa x UNB2 & 127.5 & 1006.2 & -2.1 & -6.1 \\
\hline Viçosa x Zélia & 711.0 & 237.5 & -3.3 & -0.9 \\
\hline Viçosa x CMS 43 & 444.5 & 9.4 & 1.2 & -4.3 \\
\hline Viçosa x CMS 42 & 1943.0 & 1633.7 & 1.5 & -3.1 \\
\hline Viçosa x RS 20 & -255.2 & -293.5 & -6.2 & -9.0 \\
\hline Viçosa x UEM M2 & 44.0 & 504.4 & 4.0 & -0.5 \\
\hline Viçosa x UEM J1 & 322.16 & -707.5 & 7.1 & -4.2 \\
\hline UNB2 x Zélia & -486.6 & 727.5 & 3.3 & 1.4 \\
\hline UNB 2 x CMS 43 & 326.5 & -595.7 & 3.6 & -1.5 \\
\hline UNB $2 \times$ CMS 42 & -647.6 & 667.2 & 7.0 & -3.1 \\
\hline UNB2 x RS 20 & -817.5 & -384.0 & 1.9 & -0.4 \\
\hline UNB2 x UEM M2 & -126.0 & 685.7 & 0.7 & -3.5 \\
\hline UNB2 x UEM J1 & 1205.3 & 643.6 & 4.2 & -1.2 \\
\hline Zélia x CMS 43 & 623.5 & -287.5 & 4.1 & 0.3 \\
\hline Zélia x CMS 42 & 1206.4 & 866.0 & 1.9 & 4.6 \\
\hline Zélia x RS 20 & -417.2 & 535.5 & -3.1 & -4.6 \\
\hline Zélia x UEM M2 & 21.5 & 376.2 & 1.6 & -1.8 \\
\hline Zélia x UEM J1 & 1200.5 & 1900.0 & -3.3 & -1.7 \\
\hline CMS $43 \times$ CMS 42 & 151.3 & 17.6 & 4.0 & 0.1 \\
\hline CMS 43 x RS 20 & 574.4 & -44.8 & -6.2 & -4.4 \\
\hline CMS 43 x UEM M 2 & 620.6 & 526.4 & 7.8 & -1.8 \\
\hline CMS 43 x UEM J1 & 290.1 & -337.5 & 6.9 & 3.3 \\
\hline CMS 42 x RS 20 & 675.8 & 126.3 & -0.4 & -2.2 \\
\hline CMS 42 x UEM M2 & 852.9 & 1394.8 & 4.3 & -1.5 \\
\hline CMS 42 x UEM J1 & 1768 & 347.0 & 6.7 & 1.5 \\
\hline RS 20 x UEM M2 & 542.5 & -171.2 & 0.9 & -1.0 \\
\hline RS 20 x UEM J1 & 1122.6 & 1035.8 & 3.8 & -3.5 \\
\hline UEM J1 x UEM M2 & 454.3 & 1090.0 & -1.6 & -2.1 \\
\hline
\end{tabular}

determination of this trait and confirming previous results based on the method of Griffing (1956).

For grain yield, the highest measure of heterosis was found for hybrid Viçosa $\mathrm{x}$ CMS 42. For popping expansion, the heterosis values of the hybrids CMS 43 x UEM J1, UNB2 $x$ Zélia and Beija-Flor x RS 20 were positive in both growing seasons. Nevertheless, they are not promising hybrids, in view of the low mean for popping expansion in the two growing seasons, with the exception of hybrid Beija-Flor x RS 20 with a satisfactory mean.

The mean heterosis for grain yield was significant (at 5\% probability), with an estimate of $444.75 \pm 79.0 \mathrm{~kg} / \mathrm{ha}$. For popping expansion, the mean heterosis was not significant $(\mathrm{P}>0.05)$, and consequently, the variety and specific heterosis values explained practically all heterosis observed. 
Regarding grain yield, the values of specific heterosis were high for the hybrids Viçosa x Beija-Flor, CMS 42 x Viçosa, Zélia x UEM J1 and UEM J1 x RS 20 (Table 2). In relation to popping expansion, the values of specific heterosis were high in both growing seasons evaluated for the hybrids RS 20 x Beija-Flor, UNB2 x Zélia, Beija-Flor x UEM J1, Zélia x CMS 42, CMS 42 x UEM J1 and CMS 43 x UEM J1 (Table 2). In conclusion, the two methods were almost identical in identifying the hybrids most promising for grain yield and popping expansion.

In relation to the RAPD markers, one hundred bands were analyzed, of which 62 were polymorphic and 38 monomorphic with sizes varying from 390 to $2260 \mathrm{bp}$ (Table 3). With regard to the cluster analysis based on Nei's distance (Figure 1), the genotypes UEM J1 and Zélia were the most distant while the less distant were RS 20 and UNB2. The genotypes most distant from the others were Beija-Flor, UEM J1 and Zélia, whereas RS 20 and UNB2 were

\section{Table 3. Selected RAPD primers from the kits Operon A, X and $\mathrm{W}$ for a comparison of popcorn populations in terms of number of detected loci, number of polymorphic loci and base pair size of the amplified fragments.}

\begin{tabular}{lccccc}
\hline Primer & $\begin{array}{c}\text { Nucleotide } \\
\text { sequence }\left(5^{\prime} \rightarrow 3^{\prime}\right)\end{array}$ & $\begin{array}{c}\text { Number of } \\
\text { detected loci }\end{array}$ & $\begin{array}{c}\text { Number of } \\
\text { polymorphic loci } 5 \%\end{array}$ & $\begin{array}{c}\text { Number of } \\
\text { monomorphic loci } 5 \%\end{array}$ & Fragment size (bp) \\
\hline OPA-20 & GTTGCGATCC & 11 & 8 & 3 & $760-2020$ \\
OPX-17 & GACACGGACC & 6 & 3 & 3 & $630-2100$ \\
OPX-19 & TGGCAAGGCA & 8 & 2 & 6 & $390-2030$ \\
OPW-1 & CTCAGTGTCC & 10 & 6 & 4 & $620-2200$ \\
OPW-2 & ACCCCGCAA & 7 & 4 & 3 & $890-2070$ \\
OPW-5 & GGCGGATAAG & 11 & 8 & 3 & $1010-2060$ \\
OPW-6 & AGGCCCGATG & 10 & 10 & 6 & $620-1800$ \\
OPW-7 & CTGGACGTCA & 13 & 8 & 3 & $620-1800$ \\
OPW-15 & ACACCGGAAC & 11 & 9 & 3 & $550-2700$ \\
OPW-16 & CAGCCTACCA & 13 & 62 & 38 & $750-2260$ \\
Total & & 100 & & & $390-2260$ \\
\hline
\end{tabular}

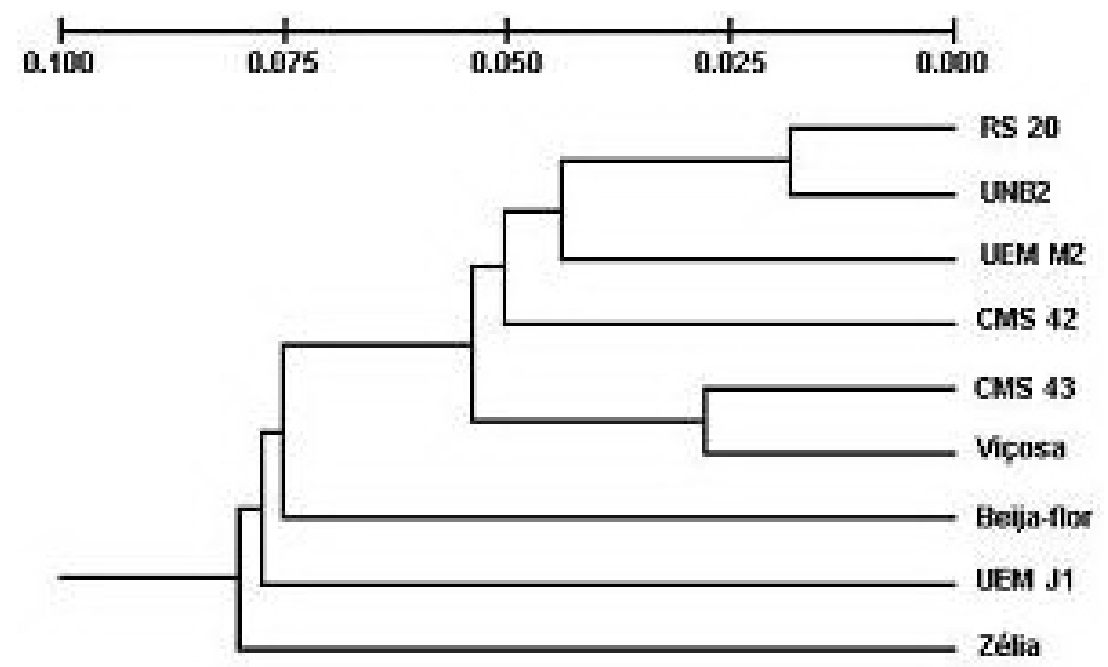

Figure 1. Dendrogram based on Nei's (1972) distance obtained by UPGMA clustering of nine popcorn cultivars. 
genetically closest. Since it was not possible to obtain the genealogy of most of these cultivars, it was presumed that RS 20 and UNB2 have one common ancestor, while the three most distant populations have different ancestors. Miranda et al. (2003) also found that the genotypes RS 20 and Beija-Flor showed a large genetic distance, in line with our results.

Regarding the three-way hybrid Zélia, it is very important to clarify that it was originated by crosses between temperate and tropical lineages, in contraposition to the other materials, in whose genetic composition there are only tropical cultivars. Maybe these different genealogies to promote the graphic genetic distance of Zélia to the other materials evaluated on this work (Figure 1). With regard to UEM J1, it is a genotype that has a poor popping expansion, which favors its allocation in separate clustering.

Evaluating the data obtained in the field experiments, the crosses that resulted in highest grain yield were Viçosa x UNB2 and UNB2 x UEM J1, which disagrees with the hypothesis that greater genetic distance is highly associated with the greater heterosis expressed by the hybrids, as should have been observed in cultivars UEM J1 and Zélia. For popping expansion, the results of the diallel analysis did not coincide either with that of genetic dissimilarity, where Beija-Flor x RS 20 and RS 20 x UEM M2 were the most outstanding crosses.

As mentioned above, to compare field and laboratory results statistically, the genetic distances obtained by RAPD markers and diallel analyses of the two most important agronomic traits - grain yield and popping expansion - were correlated (Table 4). There was no significant correlation for Nei's distances by Pearson's correlation analysis (Table 4). These

Table 4. Pearson correlation between Nei's genetic distances (1972) obtained by RAPD markers and of data of agronomic traits derived from a diallel analysis, according to Griffing's (1956) and Gardner and Eberhart's methods (1966) for two growing seasons.

\begin{tabular}{lc}
\hline Trait & Nei's distance \\
\hline GY - SCA - 98/99 & $-0.04 \mathrm{~ns}$ \\
GY - SCA - 99/2000 & $-0.20 \mathrm{~ns}$ \\
GY - specific heterosis - 98/99 & $-0.07 \mathrm{~ns}$ \\
GY - specific heterosis - 99/2000 & $-0.11 \mathrm{~ns}$ \\
GY - total heterosis - 98/99 & $-0.07 \mathrm{~ns}$ \\
GY - total heterosis - 99/2000 & $-0.17 \mathrm{~ns}$ \\
PE - SCA - 98/99 & $-0.04 \mathrm{~ns}$ \\
PE - SCA - 99/2000 & $-0.11 \mathrm{~ns}$ \\
PE - specific heterosis - 98/99 & $-0.05 \mathrm{~ns}$ \\
PE - specific heterosis - 99/2000 & $-0.04 \mathrm{~ns}$ \\
PE - total heterosis - 98/99 & $-0.03 \mathrm{~ns}$ \\
PE - total heterosis - 99/2000 & $-0.23 \mathrm{~ns}$ \\
\hline
\end{tabular}

$\mathrm{ns}=$ non-significant at probability of $0.05 ; \mathrm{GY}=$ grain yield; $\mathrm{PE}=$ popping expansion; $\mathrm{SCA}=$ specific combining ability; total heterosis = heterosis by Griffing's method; specific heterosis = heterosis by Gardner and Eberhart's method.

correlations were extremely low and non-significant (at 5\% probability), making the use of RAPD markers unfeasible for agronomic conclusions such as the prediction of hybrid heterosis and establishment of heterotic groups.

Our findings corroborate similar studies that used other types of DNA markers (Lee et al., 1989; Dudley et al., 1991; Balestre et al., 2008). Regarding RAPD markers, Rinaldi et al. (2007) also did not infer a significant correlation between heterosis and productivity in Brazilian popcorn populations. 
Different studies have reported on the successful use of molecular markers in the evaluation of the genetic diversity in maize and its association with heterosis (Lanza et al., 1997; Sun et al., 2004; Souza et al., 2008). However, these studies did not use traits related to productivity. Besides, the traits evaluated in these reports had high heritability as well mean plant height, mean ear height and mean number of days to flowering.

The low correlation between hybrid heterosis and genetic distance could be explained by the fact that the random dispersion of the RAPD markers may have been insufficient in the genome coverage, resulting in genetic distances that did not correspond with hybrid heterosis, unlike the quantitative loci or QTL markers (Bernardo, 1992). These exploit regions apparently more strongly linked to agronomic traits related to yield and popping expansion. These regions should be exploited with molecular markers, and should ideally coincide with parts of the genome with high heterozygosity in the parental crosses, aiming at the maximization of heterosis.

Other reasons that could also explain the absence of or low correlation between hybrid performance and genetic distances of the parental populations would be the different levels of dominance in the hybrids and the complementary allele frequencies between the heterotic groups used in the crosses (Bernardo, 1992).

Besides, it should be considered that genetic divergence based only on genetic distance did not agree with estimates of heterosis, where not only genetic distance takes place but also genetic complementation, as the sum of deviation dominant loci.

Relatively few suppositions have been proposed to explain these low correlations genetically, even considering the studies with different maize genotypes and also with different molecular markers. The fact is that this problem is not completely solved and will need further investigations aimed at analysis techniques that use molecular markers and that search for genetic explanations for the existence of significant correlations between hybrid performance and genetic distance for some plant species such as rice, and the absence of correlation in others, as in the case of maize and soybean.

The RAPD technique was efficient in detecting polymorphisms and determining genetic distances in popcorn. Nevertheless, genetic distance did not correlate significantly with the heterosis values and the specific combining ability of agronomic traits of the hybrids and is therefore not efficient in predicting hybrid performance.

\section{ACKNOWLEDGMENTS}

Research supported by Conselho Nacional de Pesquisa (CNPq) and Fundação Araucária.

\section{REFERENCES}

Aguiar CG, Schuster I, Amaral AT Jr, Scapim CA, et al. (2008). Heterotic groups in tropical maize germplasm by test crosses and simple sequence repeat markers. Genet. Mol. Res. 7: 1233-1244.

Amaral Júnior AT, Casali VWD, Cruz CD and Finger FL (1999). Genetic inferences on yield and quality of tomato in a diallel cross. [Inferências genéticas na produção e qualidade de tomateiro sob cruzamento dialélico]. Pesq. Agropec. Bras. 34: 1407-1416.

Andrade RA, Cruz CD, Scapim CA, Silvério L, et al. (2002). Diallel analysis of the combining ability of popcorn cultivars. [Análise dialélica da capacidade combinatória de variedades de milho-pipoca]. Acta Sci. Agron. 24: 1197-1204.

Balestre M, Machado JC, Lima JL, Souza JC, et al. (2008). Genetic distance estimates among single cross hybrids and 
correlation with specific combining ability and yield in corn double cross hybrids. Genet. Mol. Res. 7: 65-73.

Barbosa-Neto JF, Sorrells ME and Cisar G (1996). Prediction of heterosis in wheat using coefficient of parentage and RFLP-based estimates of genetic relationship. Genome 39: 1142-1149.

Bernardo R (1992). Relationship between single-cross performance and molecular marker heterozygosity. Theor. Appl. Genet. 83: 628-634.

Cerna FJ, Cianzio SR, Rafalski A, Tingey S, et al. (1997). Relationship between seed yield heterosis and molecular marker heterozygosity in soybean. Theor. Appl. Genet. 95: 460-467.

Crossa J and Franco J (2004). Statistical methods for classifying genotypes. Euphytica 137: 19-37.

Cruz CD (2006). Programa Genes: Biometria. Editora Universidade Federal de Viçosa, Viçosa.

Cruz CD and Vencovsky R (1989). Comparação de alguns métodos de análise dialélica. Rev. Bras. Genet. 12: 425-438.

Cruz CD and Carneiro PCS (2003). Modelos Biométricos Aplicados ao Melhoramento Genético. Vol. 2. Universidade Federal de Viçosa, Viçosa.

Cruz CD, Regazzi AJ and Carneiro PCS (2004). Modelos Biométricos Aplicados ao Melhoramento Genético. Vol. 1. Universidade Federal de Viçosa, Viçosa.

Dandolini TS, Scapim CA, Amaral Júnior AT, Mangolin CA, et al. (2008). Genetic divergence in popcorn lines detected by microsatellite markers. Crop Breed. Appl. Biotechnol. 8: 313-320.

Daros M, Amaral Júnior AT, Pereira MG, Santos FS, et al. (2004a). Correlações entre caracteres agronômicos em dois ciclos de seleção recorrente em milho-pipoca. Cienc. Rural 34: 1389-1394.

Daros M, Amaral Júnior AT, Pereira MG, Santos FS, et al. (2004b). Recurrent selection in inbred popcorn families. Sci. Agric. 61: 609-614.

Dofing SM, D'Croz-Maso N and Thomas Compton MN (1991). Inheritance of expansion volume and yield in two popcorn $\mathrm{x}$ dent corn crosses. Crop Sci. 31: 715-718.

Dudley JW, Saghai Maroof MA and Rufener GK (1991). Molecular markers and grouping of parents in maize breeding programs. Crop Sci. 31: 718-723.

Franco J, Crossa J and Ribout JM (2001). A method for combining molecular markers and phenotypic attributes for classifying plant genotypes. Theor. Appl. Genet. 103: 944-952.

Freitas Júnior SP, Amaral Júnior AT, Pereira MG, Cruz CD, et al. (2006). Combining ability in popcorn by circulant diallel. Pesq. Agropec. Bras. 41: 1599-1607.

Garcia E, Jamilena M, Alvarez JI, Arnedo T, et al. (1998). Genetic relationships among melon breeding lines revealed by RAPD markers and agronomic traits. Theor. Appl. Genet. 96: 878-885.

Gardner CO and Eberhart SA (1966). Analysis and interpretation of the variety cross diallel and related populations. Biometrics 22: 439-452.

Gonçalves LS, Rodrigues R, Amaral AT Jr, Karasawa M, et al. (2008). Comparison of multivariate statistical algorithms to cluster tomato heirloom accessions. Genet. Mol. Res. 7: 1289-1297.

Gonçalves LS, Rodrigues R, do Amaral Junior AT, Karasawa M, et al. (2009). Heirloom tomato gene bank: assessing genetic divergence based on morphological, agronomic and molecular data using a Ward-modified location model. Genet. Mol. Res. 8: 364-374.

Griffing B (1956). Concept of general and specific combining ability in relation to diallel crossing system. Aust. J. Biol. Sci. 9: 463-493.

Hahn V, Blankenhorn K, Schwall M and Melchinger AE (1995). Relationships among early European maize inbreds. III. Genetic diversity revealed with RAPD markers and comparison with RFLP and pedigree data. Maydica 40: 299-310.

Iqbal A, Khan AS, Khan IA, Awan FS, et al. (2007). Study of genetic divergence among wheat genotypes through random amplified polymorphic DNA. Genet. Mol. Res. 6: 476-481.

Lanza LLB, Souza Júnior CL, Ottoboni LMM, Vieira MLC, et al. (1997). Genetic distance of inbred lines and prediction of maize single-cross performance using RAPD markers. Theor. Appl. Genet. 94: 1023-1030.

Larish LLB and Brewbaker JL (1999). Diallel analyses of temperate and tropical popcorns. Maydica 44: 279-284.

Lee M, Godshalk EB, Lamkey KR and Woodman WW (1989). Association of restriction fragment length polymorphisms among maize inbreds with agronomic performance of their crosses. Crop Sci. 29: 1067-1071.

Legesse BW, Myburg AA, Pixley KV, Twumasi-Afriyie S, et al. (2008). Relationship between hybrid performance and AFLP based genetic distance in highland maize inbred lines. Euphytica 162: 313-323.

Lorencetti C, Carvalho FIF, Oliveira AC, Valério IP, et al. (2006). Genetic distance and its association with heterosis and performance of hybrids on oat. Pesq. Agropec. Bras. 41: 591-598.

Miranda GV, Coimbra RR, Godoy CL, Souza LV, et al. (2003). Potential to breeding and genetic divergence in popcorn cultivars. Pesq. Agropec. Bras. 38: 681-688.

Miranda GV, Souza LV, Galvão JCC, Guimarães LJM, et al. (2008). Genetic variability and heterotic groups of Brazilian 
popcorn populations. Euphytica 162: 431-440.

Mohammadi SA and Prasanna BM (2003). Analysis of genetic diversity in crop plants - salient statistical tools and considerations. Crop Sci. 43: 1235-1248.

Nei M (1972). Genetic distance between populations. Am. Nat. 106: 283-292.

Pejic I, Ajmone-Marsan P, Morgante M, Kozumplick V, et al. (1998). Comparative analysis of genetic similarity among maize inbred lines detected by RFLPs, RAPDs, SSRs, and AFLPs. Theor. Appl. Genet. 97: 1248-1255.

Pereira MG and Amaral Júnior AT (2001). Estimation of genetic components in popcorn based on the nested design. Crop Breed. Appl. Biotechnol. 1: 3-10.

Rangel RM, Amaral Júnior AT, Viana AP, Freitas Júnior SP, et al. (2007). Prediction of popcorn hybrid and composite means. Crop Breed. Appl. Biotechnol. 7: 287-295.

Rangel RM, Amaral AT Jr, Scapim CA, Freitas SP Jr, et al. (2008). Genetic parameters in parents and hybrids of circulant diallel in popcorn. Genet. Mol. Res. 7: 1020-1030.

Rinaldi AR, Carpentieri-Pípolo V, Gerage AC, Ruas CF, et al. (2007). Correlation between heterosis and genetic divergence estimated of diallel crosses and RAPD molecular markers in populations of popcorn. Bragantia 66: 183-192.

Santos FS, Amaral Júnior AT, Freitas Júnior SP, Rangel RM, et al. (2008). Genetic gain prediction of the third recurrent selection cycle in a popcorn population. Acta Sci. Agron. 30: 651-655.

Scapim CA, Carvalho CGP and Cruz CD (1995). Uma proposta de classificação dos coeficientes de variação para a cultura do milho. Pesq. Agropec. Bras. 30: 683-686.

Scapim CA, Pacheco CAP, Tonet A, Braccini AL, et al. (2002). Diallel analyses and heterosis in popcorn varieties. Bragantia 61: 219-230.

Silva TA, Pinto RJB, Scapim CA, Mangolin CA, et al. (2009). Genetic divergence in popcorn genotypes using microsatellites in bulk genomic DNA. Crop Breed. Appl. Biotechnol. 9: 31-36.

Simon GA, Scapim CA, Pinto RJB, Pacheco CAP, et al. (2004). Inbreeding depression in popcorn populations. Bragantia 63: 55-62.

Souza SGH, Carpentieri-Pípolo V, Ruas CF, Carvalho VP, et al. (2008). Comparative analysis of genetic diversity among the maize inbred lines (Zea mays L.) obtained by RAPD and SSR markers. Braz. Arch. Biol. Technol. 51: 183-192.

Sun GL, William M, Liu J, Kasha KJ, et al. (2004). Microsatellite and RAPD polymorphisms in Ontario corn hybrids are related to the commercial sources and maturity ratings. Mol. Breed. 7: 13-24.

Verma RK and Singh TP (1979). Inter-relation among certain quantitative traits in popcorn. Mysore J. Agric. Sci. 13: 15-18.

Viana JMS and Matta FP (2003). Analysis of general and specific combining abilities of popcorn populations, including selfed parents. Genet. Mol. Biol. 26: 465-471.

Vieira EA, Carvalho FIF, Bertan I, Kopp MM, et al. (2007). Association between genetic distances in wheat (Triticum aestivum L.) as estimated by AFLP and morphological markers. Genet. Mol. Biol. 30: 392-399.

Vilarinho AA, Viana JMS, Câmara TMM and Santos JF (2002). Seleção de progênies endogâmicas $S_{1}$ e $S_{2}$ em um programa de melhoramento intrapopulacional de milho pipoca. [S1 and S2 imbred progenies selection in program for intrapopulational improvement of popcorn]. Acta Sci. Agron. 24: 1419-1425.

Vilarinho AA, Viana JMS, Santos JF and Câmara TMM (2003). Eficiência da seleção de progênies $S_{1}$ e $S_{2}$ de milhopipoca, visando à produção de linhagens. Bragantia 62: 9-17.

Vilela FO, Amaral Júnior AT, Pereira MG, Scapim CA, et al. (2008). Effect of recurrent selection on the genetic variability of the UNB-2U popcorn population using RAPD markers. Acta Sci. Agron. 30: 25-30.

Williams JG, Kubelik AR, Livak KJ, Rafalski JA, et al. (1990). DNA polymorphisms amplified by arbitrary primers are useful as genetic markers. Nucleic Acids Res. 18: 6531-6535.

Xiao J, Li J, Yuan L, McCouch SR, et al. (1996). Genetic diversity and its relationship to hybrid performance and heterosis in rice as revealed by PCR-based markers. Theor. Appl. Genet. 92: 637-643. 